\title{
МЕТОДОЛОГІЯ СЛОВОЦЕНТРИЗМУ МОВНОЇ ОСВІТИ ДІТЕЙ У ТВОРАХ ФРАНЦУЗЬКИХ ФІЛОСОФІВ ХХ СТОЛІТТЯ
}

Полєвікова О.Б. Методологія словоцентризму мовної освіти дітей у творах французьких філософів ХХ століття.

Автор статті досліджує розвиток поглядів на природу та функції мови у творах французьких філософів XX століття як методологічну основу словоцентричного підходу до мовної освіти й мовленнєвого розвитку дітей старшого дошкільного й молодшого шкільного віку.

Ключові слова: словоцентризм, мовна освіта, методологія, французькі філософи ХХ століття.

Полевикова О. Б. Методология словоцентризма языкового образования детей в произведениях французских философов XX века.

Автор статьи исследует развитие взглядов на природу и функции языка в произведениях французских философов XX века как методологическую основу словоцентричного подхода к языковому образованию и речевому развитию детей старшего дошкольного и младшего школьного возраста.

Ключевые слова: словоцентризм, речевое образование, методология, французские философы XX века.

Polevikova O. B. Methodology of word-centerism to children's language education in the works of French philosophers of the twentieth century.

The author of the article examines the development of views on language nature and function in the works of French philosophers of the twentieth century as the methodological basis of word-centerism approach to language education and speech development of preschool and primary school aged children.

Key words: word-centerism, language education, French philosophers of the twentieth century.

Перехід на нові державні стандарти у дошкільній підготовці та початковій школі актуалізують пошуки ефективних шляхів забезпечення якісної освіти дітей взагалі, мовної зокрема.

У лінгводидактиці одним із таких шляхів пропонується словоцентричний підхід (словоцентризм), тобто розроблення і впровадження методів і прийомів навчання мови словом задля реалізації завдань мовної освіти й мовленнєвого розвитку дітей (О. Антонова, А. Богуш, М. Вашуленко, Н. Гавриш, А. Дейкіна, Л. Логвінова, Н. Луцан, Л. Федоренко).

Оскільки лінгводидактика як наукова дисципліна грунтується на певних методологічних засадах, потреба з'ясування методологічних основ словоцентричного підходу є незаперечною.

На Заході методологічні проблеми мовознавства вивчали Г. Фреге, Б. Рассел, К. Айдукевич, В. Квін, М. Хомський та ін. Не став винятком і постмодернізм світоглядна орієнтація, що в останні десятиріччя стає панівною в сучасній філософській думці. Коріння постмодернізму сягає структуралізму й постструктуралізму, тому дуже часто як синоніми «постмодернізму» вживають поняття «постструктуралізм», «неоструктуралізм», «деконструктивізм», виникає «постструктуралістськодеконструктивістсько-постмодерністський» комплекс [2].

Проте, аналіз головних рис постмодернової ідеології в контексті нашого дослідження потребує подальших наукових розвідок.

Meта статmi - з'ясувати розвиток поглядів на природу та функції мови у творах французьких філософів XX століття як методологічної основи словоцентричного підходу до мовної освіти й мовленнєвого розвитку дітей старшого дошкільного й молодшого шкільного віку. 
Реалізація поставленої мети вимагатиме розв'язання таких завдань:

1) обгрунтувати проблему внутрішнього механізму мови у праці М. Фуко «Слова та речі»;

2) здійснити аналіз теорії смислу Ж. Дельоза.

Мова опиняється в центрі уваги філософії постмодерну, яка намагається по-своєму тлумачити iï природу, дати епістемологічну оцінку іiі функцій, 3'ясувати сутність дихотомії «означуване - означальне», підкреслити роль означального як довільної й непов'язної точки в полі смислів. Для ілюстрації цієї тези звернімося до ідей М. Фуко та Ж. Дельоза. За всієї оригінальності їхніх концепцій створюється враження дивовижної зв'язності, наступності їхніх ідей.

Цілком слушно поставити на перше місце у розвитку лінгвістичної проблематики М. Фуко, оскільки його ідеї багато в чому визначили погляди інших філософів і необхідні для розуміння ідей Ж. Дельоза. Також слід враховувати концепцію Ф. Соссюра, від якої відштовхувалися наші автори в своїх лінгвістичних розвідках.

Головним моментом концепції Ф. Соссюра є введення дихотомії «мова - мовлення»: «поняття мови не збігається з поняттям мовленнєвої діяльності взагалі; мова - тільки певна частина, щоправда, найважливіша частина мовленнєвої діяльності. Вона $є$ соціальним продуктом, сукупністю необхідних умовностей, прийнятих колективом, щоб забезпечити реалізацію, фіксування здатності до мовленнєвої діяльності, яка існує у кожного носія мови» [6, с. 47]. У концепції Ф. Соссюра спрощено питання про співвідношення плану вираження та плану змісту в мові, між ними існує відношення, яке називають асоціацією означального та означуваного. Це припущення має своїм наслідком те, що знімаються майже всі питання, пов'язані 3 нетотожністю значення знака в мовній системі та у функціонуванні мовлення. Запам'ятаймо ще одну тезу Ф. Соссюра про те, що означуване та означальне - це два боки знака - як лицевий та зворотний боки аркуша паперу. Це визначення Ф. Соссюра неодноразово згадують фігуранти нашого дослідження.

Якщо спробувати сформулювати головний принцип, на якому грунтується концепція мови М. Фуко, то, безперечно, це тлумачення мови як «єдиного апріорі» культури. Одним із головних завдань своєї діяльності М. Фуко вважав створення особливої дисципліни «археології знання», яка була б здатна виокремлювати історично мінливі системи умов пізнання й культури, визначувані панівними в певний період часу відношеннями між «словами» та «речами». Підгрунтям концепції французького дослідника $є$ дихотомія «я мислю - я говорю». За панування першого елемента дихотомії домінантною була філософія самосвідомості, рефлексії, за панування елемента «слово про слово» суб'єкт зникає, мова починає поставати як самостійна й рівноправна інстанція, що призводить до розриву між буттям мови та свідомістю в усій іiї самототожності. Ці ідеї становлять сутність праці М. Фуко «Слова та речі». Згідно з позицією автора, мова у своєму розвитку й функціюванні проходить немовби три етапи, що відповідають трьом епістемам, специфіка яких полягає у співвідношенні «слів та речей», у ролі мови в культурі:

1) Відродження XV - XVI сторіч - мова постає як річ серед речей;

2) класичний раціоналізм XVII - XVIII сторіч - мова постає як прозорий засіб вираження думки;

3) сучасна епісистема, починаючи з XIX сторіччя, мова постає як самостійна система.

За допомогою праці «Слова та речі» спробуємо простежити історію розвитку мови, як іiі бачив М. Фуко. Науковець відзначає величезну роль, яку аж до кінця XVI сторіччя в розвитку знання, у культурі західних країн відігравала категорія подібності. Значною мірою вона визначала тлумачення та інтерпретацію текстів, організовувала гру символів. Усе розглядали як копію іншого предмета або явища: земля повторювала небо, живопис копіював простір, людина - природу. «І вистава - чи то свято, чи то знання - поставала як повторення: театр життя або дзеркало світу - ось як іменували будь-яку мову, ось як вона сповіщала про себе й утверджувала своє право на самовираження» [4, с. 54]. Між знаком та тим, що він означає, єдиною сполучною ланкою була схожість, тому знання XVI 
сторіччя було приречене на те, щоб пізнавати незмінно одне й те саме, але приходити до цього пізнання лише в підсумку так ніколи й не завершуваного безконечного руху. «Мова розташована на півшляху між зримими формами природи та таємничими відповідностями езотеричних міркувань. Мова - це роздроблена, внутрішньо розколота й видозмінена природа, що втратила свою вихідну прозорість; це таємниця, що несе в собі, але на поверхні, доступні розшифруванню знаки того, що вона позначає. Мова водночас $\epsilon$ прихованим одкровенням, яке помалу повертає собі дедалі більшу ясність» [4, с. 72].

Із часом зникла схожість мови з речами, які були першопричиною іiі виникнення, й мови розпалися, стали несумісними одна з одною. Мова продовжує існувати як засіб виявлення і висловлювання істини, вона стає «образом світу, що спокутує своє гріхи й починає дослухатися слова істини» [4, с. 73].

До XVII сторіччя система знаків у рамках західної філософської парадигми була потрійною - означуване, означальне й «випадок», відтак стає бінарною й визначається зв'язком означуваного та означального. Мова замість того, щоб існувати як матеріальне письмо речей, здобуває свій простір лише в загальному шерегу репрезентативних знаків. Це порушує проблему співвідношення означуваного та означального, смислу та значення. Починають розмежовуватися слова та речі. Завданням мовлення постає висловлювання того, що $є$, але воно вже не є нічим понад те, про що йдеться. Зростає роль літератури, яка, починаючи з XIX сторіччя, знов актуалізує мову в іï бутті. «Мова ставить крапку на своїй колишній спорідненості 3 речами і входить у ту самотню суверенність, 3 якої вона повернеться у своєму грубому бутті, лише ставши літературою, оскільки подібність входить тут у добу, яка для неї є добою вигадливості й фантазії» [4, с. 83].

Класичну добу характеризує подвійне становище мови, яка посідала водночас і панівне, і непомітне місце. Перше було можливе завдяки властивості слів репрезентувати думки, але мова репрезентувала їі так, як думка уявляла себе сама. Ніякий знак не виникає, ніяке слово не висловлюється, ніяке речення не має ніякого змісту без гри уявлення, яке абстрагується від себе самого, роздвоюється й відображається в іншому, еквівалентному йому уявленні. Уявлення виходять у простір, який є для них властивим і внутрішня структура якого породжує смисл. Саме в цьому проміжку й перебуває мова. Слова вказують на думку всередині уявлення, мова включена в мереживо думки й уплетена в саму тканину, яку вона розгортає. Мова - це не зовнішній вияв думки, а сама думка. «Мова не має більше ні іншого місця, крім уявлення, ні іншої цінності, як у ньому: вона існує в тому просторі, який уявлення може впорядкувати» [4, с. 112].

Мова $є$ вихідною формою будь-якої рефлексії, першою темою будь-якої критики. У словах стає знанням усе, що уявляють, i навпаки, це знання тепер стає тим, що повсякденно уявляють.

У XIX сторіччі починається аналіз мови, що розглядається як сукупність звуків окремо від літер. Таке тлумачення мови породжує два наслідки: 1) мові знову починають приписувати доглибинну здатність вираження; 2) мову пов'язують 3 цивілізаціями не на рівні досягнутого нею пізнання, а за допомоги духу народу, що їх породив. Мова стала об'єктом наук, постаючи в сучасній епістемі як самостійна система.

В аналізі концепції Ж. Дельоза ми неодноразово спостерігаємо з ідеї інших мислителів, оскільки автор явно чи неявно апелює до М. Хайдеггера, до Г. Гадамера, до П. Рікьора.

Те, що пропонує нам у своїй праці «Логіка смислу» Ж. Дельоз, істотно відрізняється від написаного до нього. Спробуємо показати всю яскравість і непересічність його теорії смислу, утвореної серією парадоксів, оскільки смисл- це неіснуюча сутність, тісно пов'язана 3 нонсенсом, а сутність парадокса полягає в утвердженні двох смислів одночасно, у відсутності розрізнення на до та після, на минуле та майбутнє.

Проблема смислу є такою ж давньою, як проблема мови. Практично представники всіх філософських напрямків вважали за свій обов'язок зробити внесок в «огранення» поняття «смисл». Не маючи можливості розглядати всю історію цього поняття, зупинимося лише на деяких персоналіях. 
Звернемося до авторитету М. Хайдеггера, який розглядав смисл у тісному зв’язку з мовленням: «про смисл можна кожного разу говорити тільки тоді, коли ми маємо справу з обдумуванням, міркуванням, конструюванням, визначенням. Смисл перебуває у тісному взаєзв'язку з тим, що ми в найзагальнішому значенні слова називаємо мисленням, причому під мисленням розуміємо не уявлення в широкому сенсі цього слова, а мислення, яке може бути правильним або неправильним, істинним або хибним. Кожному судженню іманентно притаманний певний смисл. Форма, у якій смисл постає в дійсності,- це значимість, тобто форма процесу судження» [5, с. 163].

Для Г.-Г. Гадамера мислення, яке шукає собі виразу, співвіднесене не з духом, а із самою річчю, образом якої є слово, у слові завершується пізнання, саме в ньому повністю мислиться зміст речі. Тому «смисл слова не може бути відокремлений від самої події повідомлення. Навпаки, сам смисл має характер події» [1, с. 496].

Відомий французький філософ П. Рікьор має свою точку зору на проблему смислу. Причому в розв'язанні цієї проблеми він навіть відходить від позицій свого кумира Е. Гуссерля. У концепції Е. Гуссерля джерелом смислу $\epsilon$ переважно теоретична свідомість, афективні та вольові виміри людини вкорінені в таких свідомих актах, як сприйняття та уявлення. Згідно з поглядами П. Рікьора, первинними постають афективні та вольові акти, які й є джерелом смислу. Науковець зазначає: «Для того, щоб нам зрозуміти самих себе, ми намагаємося тоталізувати не лінгвістичні закони, а смисл слів, стосовно якого лінгвістичні закони є завжди несвідомим посередницьким інструментом. Я прагну пізнати самого себе, оволодіваючи смислом слів усіх людей, саме щодо цього прихований час стає історичністю традиції та інтерпретації» [16, с. 80]. Для П. Рікьора смисл має властивість множинності: «Я позначаю певну дію смислу, відповідно до якої якийсь вираз, що має змінюване значення, позначаючи одну річ, водночас позначає й іншу річ, не перестаючи при цьому позначати першу» [3, с. 97].

Усі ці ідеї знаходимо в концепції смислу Ж. Дельоза, водночас він привносить у розуміння проблеми смислу безліч нових, оригінальних рис. Смисл не зводиться до індивідуальних станів речей, конкретних образів, особистих вірувань та універсальних або загальних понять, тобто йому байдуже специфічне та загальне, одиничне та універсальне, особисте та безособове. Ми можемо тільки побічно судити про нього на підставі того кола, за яким нас ведуть звичні відношення речення.

Ж. Дельоз виокремлює дві властивості смислу:

1) смисл не існує сам по собі, поза реченням, яке його виражає (тут знову доречно згадати М. Хайдеггера та його ідею про те, що смисл - це артикульоване у висловлюванні та мовленні);

2) смисл не виявляється повністю в реченні, він є тим, що надається як атрибут, але він зовсім не атрибут речення, радше він атрибут речі або стану речей. Атрибутом речення $\epsilon$ предикат, який приписано суб'єктові та який може бути виражений навіть займенником.

Ж. Дельоз полемізує з П. Рікьором, у якого атрибутом речі може бути і іменник, оскільки іменник та дієслово $є$ категоріями дискурсу, завдяки яким наші знаки певним чином «адресовані універсамові», якщо мати на увазі простір і час. Перетворюючи слова на іменник та дієслово, ці категорії роблять наші знаки здатними оволодівати реальністю. У Ж. Дельоза атрибутом речі завжди є дієслово, оскільки приписується як атрибут тієї речі, яку зазначає суб’єкт, або того стану речей, який позначається всім реченням. Атрибут не існує поза реченням, яке виражає його, позначаючи річ.

«Смисл - це і виражене реченням, і атрибут стану речей» [6, с. 38]. Смисл і є подія за умови, що подія не змішується зі своїм просторово-часовим здійсненням у стані речей. Подія за самою суттю належить мові, а мова - те, що висловлюють про речі. Смисл хоча й не існує поза реченням, яке його виражає, але все ж є атрибутом не самого речення, а стану речей. У речах оживають події, наявні у мові. Речі та речення перебувають по два боки межі, яка репрезентована смислом. Дійшовши такого висновку, Ж. Дельоз уважає за 
необхідне розглянути смисл окремо, в особливих серіях парадоксів, які мають внутрішній характер. Він виокремлює чотири такі парадокси.

1. Парадокс невизначеного поширення або регресу - сутність його полягає в тому, що кожний, хто говорить, уже занурений у смисл, інакше він не може не тільки говорити, але й думати. Виходить безконечний регрес того, що мається на увазі, який свідчить як про безсилля того, хто говорить, так і про всесилля мови.

2. Парадокс стерильного роздвоєння або сухого повторення - тільки тіла діють і зазнають впливу дій, але не безтілесні сутності, які є лише результатами дій та зазнавання впливу дій, здійснених тілами. Виокремлений із речення, смисл є незалежним від нього, оскільки призупиняє як його ствердження, так і заперечення. Ж. Дельоз уважає, що ці два парадокси становлять два терміни альтернативи, або одне, або інше. Перший змушує нас суміщати воєдино щонайбільшу силу з повним безсиллям, а другий змушує розв'язувати завдання, як пов'язати стерильність смислу стосовно речення, із якого він був виокремлений.

3. Парадокс нейтральності, або третій стан сутності. Смисл зовсім не змінюється від речення до речення, протиставлюваних щодо кількості, якості, відношення або модальності. Смисл байдужий до всіх опозицій, оскільки вони - тільки модуси речення, розглядувані у відношеннях денотації та сигніфікації, а не аспекти смислу, що виражається реченням. Із цього випливає останній, четвертий парадокс.

4. Парадокс абсурду, або неможливих об'єктів, - речення, що позначають несумісні об'єкти, мають смисл, хоча ці об'єкти й існують без значення, тобто є абсурдними. Отже, виходить, що смисл - це неіснуюча сутність, щось на кшталт нонсенсу. Ж. Дельоз стверджує, що функція парадокса полягає в тому, щоб перебігати різнорідні серії, координувати їх, змушувати резонувати, сходитися в одній точці, а також уводити в кожну із серій різні диз'юнкції. Що є підставою виникнення серії? Відповідь проста ім'я. Відомо, що кожне ім'я, яке позначає смисл попереднього імені, має більш високий ранг як стосовно самого цього імені, так і стосовно того, що воно позначає. Тобто, кожне ім'я береться спочатку з точки зору того позначення, яке воно здійснює, а відтак того смислу, який воно виражає, оскільки саме цей смисл і $є$ денотатом для іншого імені.

Отже, ми отримуємо одночасність двох серій, одна 3 яких є означальним, а інша означуваним. У Ж. Дельоза означуване - це поняття, ім'я або, ширше, річ, яка може бути задана на підставі тієї відмінності, яку цей аспект смислу встановлює з цією річчю. Подія, зрозуміла як ідеальний логічний атрибут стану речей, - означальне. Означуване - це стан речей, разом з його властивостями та реальними відносинами, означальне - саме речення, оскільки смисл або позначене відмінні від нього. Одна із серій завжди постає як означальне, інша - як означуване, навіть якщо ці ролі взаємозамінюються при зміні точок зору. Терміни кожної серії перебувають у неперервному зміщенні стосовно термінів іншої серії, між ними є істотна розбіжність, без якої жодна із серій не відкривалася б в іншу.

Регулюються серії також і езотеричними словами, які можуть бути кількох типів:

1) слова, що скорочують, - створюють зв'язність, синтез послідовності, характерний для окремих серій. Вони утворюються взаємодією складових елементів одного або кількох речень, що розташовані одне за одним задля виокремлення глобального смислу всього речення для того, щоб іменувати його одним словом;

2) слова, що циркулюють, - езотеричні слова, які є синтезом співіснування і спрямовані на те, щоб забезпечити кон'юнкцію двох серій різнорідних речень або вимірів речення;

3) диз'юнктивні слова - езотеричні слова особливого типу, так звані слова-гаманці, визначальною ознакою яких є те, що вони скорочують кілька слів і згортають у собі кілька смислів (наприклад, «зломанливий» - «злий + оманливий»). Функція слова-гаманця полягає в тому, що воно слугує для розгалуження тієї серії, до якої воно було введене.

Парадокс, парадоксальний елемент нерозривно пов'язаний із серійністю. Він постає водночас і як слово $=\mathrm{x}, \mathrm{i}$ як річ $=\mathrm{x}$. Оскільки він пов'язаний одразу 3 двома серіями, то має два боки, які ніколи не перебувають у рівновазі, не з'єднуються разом, не зливаються, 
оскільки парадоксальний елемент завжди залишається у нерівновазі стосовно самого себе. Від типу езотеричного слова залежить і різновид парадокса, а саме у парадоксах мова досягає своєї щонайвищої потужності.

Отже, філософські концепції французького авангарду мають ту філософську, культурологічну, наукову традицію, яка об'єднує їx, дає їм виток i наснагу для подальшого розвитку і процвітання.

М. Фуко порушує проблему внутрішнього механізму мови, який визначає індивідуальну природу мови як цілого, у іiі співвіднесенні з іншими мовами, порушує питання про гносеологічну цілісність мови та світу.

Іншим яскравим представником французького постмодерну є Ж. Дельоз. Ми вже аналізували його концепцію мови, тому тут доречно окреслити тільки головні положення дельозівського тлумачення мови. Сутність його полягає в тому, що мова має подієвий характер, тобто стає можливою тільки завдяки події, адже саме вона породжує в нас бажання, яке стає квазіпричиною всього того, що відбувається, відображає саму цю подію. Оскільки подія має протяжність, то вона існує в часі, має минуле й майбутнє. Саме майбутнє уможливлює виникнення світу безтілесних ефектів, ефектів поверхні, які тільки й уможливлюють мову, позаяк звуки перестають бути тільки простими сполученнями тілесних дій та страждань. Звуки дістають тут дві головні властивості: мати смисл і не належати тілам у вигляді їхніх фізичних якостей, а поставати в ролі сигніфікації, маніфестації, денотації. Межею між речами та уявленнями у Ж. Дельоза є смисл. Сама мова можлива лише завдяки межі, що відділяє іiі від речей та тіл, дає їй існування як системі речень; саме через відношення, атрибутивно притаманні реченню, й здійснюється зв'язок між подією та мовою. Подія є результатом дій, суміші й страждань тіл, тому вона за природою відрізняється від того, результатом чого є, будучи атрибутом тіл і положень речей, а не фізичною якістю. Цей атрибут існує в реченні не як ім'я тіл або якостей і не як суб'єкт або предикат, а як виражене реченням, згорнуте в дієслові. Подія, що відбувається в положення речей, і смисл, присутній у реченні, - одне й те саме. Подія виносить на поверхню два терміни - тіла, атрибутом яких $\epsilon$, і речення, які становлять у цьому розумінні сутність, що підлягає вираженню. Отже, мова та світ, слова та речі тісно взаємопов'язані, саме подія, співбуття, буття перетворюють звуки на мову, відділяють їх від звукових якостей речей, шумів, створюваних тілами, уможливлюють мову.

Людина ніколи б не досягла сучасного рівня розвитку, без використання мовної системи, тому немає нічого дивного в тій величезній увазі, яку філософи приділяють цьому феноменові. Представники французького постмодернізму не стали винятком 3 правила, вони лише продовжили багатовікову традицію, але їхня точка зору відповідає нашій суперечливій добі сучасності.

Перспективи подальших досліджень убачаємо в з'ясуванні філософських засад словоцентричного підходу до мовної освіти й мовленнєвого розвитку дітей старшого дошкільного та молодшого шкільного віку, зокрема розвитку лінгвофілософської думки в Україні.

\section{Література}

1. Гадамер X.-Г. Истина и метод: Основы филос. герменевтики: [пер. с нем.] / общ. ред. и вступ. ст. Б. Н. Бессонова. - М. : Прогресс, 1988. - 704 с. 2. Диб'як Н. Філософія мови. Шляхи до істини / Н. Диб'як // Дивослово. - 1997. - №5-6. - С.15-16. 3. Танатография Эроса: Жорж Батай и французская мысль середины XX века: [сб. статей А. Бретона, Ж. П. Сартра, Г. Марселя, М. Бланшо, Р. Барта и др., а также избр. работы самого Ж. Батая]. - СПб. : Мифрил, 1994. - 346 с. 4. Фуко М. Археологія знання / Мішель Фуко. - Київ : Знання, 1996. - 156 с. 5. Хайдеггер М. Время и бытие: Статьи и выступления / [сост., пер. с нем. и ком. В. В. Бибихина]. - М. : Республика, 1993. - 447 с. 6. Хесле В. Гении философии нового времени / В. Хесле // М. : Наука, 1992. $-224 \mathrm{c}$. 